\title{
Cloning, sequencing and genetic mapping of a Bacillus subtilis cell wall hydrolase gene
}

\author{
AKIO KURODA and JUNICHI SEKIGUCHI* \\ Department of Applied Biology, Faculty of Textile Science and Technology, Shinshu University, 3-15-1 Tokida, \\ Ueda-shi, Nagano 386, Japan
}

(Received 3 April 1990; revised 2 July 1990; accepted 11 July 1990)

\begin{abstract}
We have cloned DNA fragments from Bacillus subtilis 168 S into Escherichia coli, which produced a lytic zone on an agar medium containing $B$. subtilis cell wall. Sequencing of the fragments showed the presence of an open reading frame (ORF) which encodes a polypeptide of 272 amino acids with a molecular mass of $29919 \mathrm{Da}$. The deduced amino acid sequence showed considerable homology with that of the cell wall hydrolase gene of Bacillus sp. (Potvin, C., Leclerc, D., Tremblay, G., Asselin, A. \& Bellemare, G. (1988). Molecular and General Genetics 214, 241-248). Accordingly, the gene was designated $c w l A$, for cell wall lysis. The $\mathbf{N}$-terminal amino acid sequence of $c w l A$ gene product prepared from a $E$. coli clone was AIKVVKNLVSKSKYGLKCPN, which is consistent with that of the deduced sequence starting from Ala at second position from the initiation codon of the $c w l A$ gene. A presumed $\sigma^{\mathrm{A}}$ promoter and a rho-independent terminator were found upstream and downstream of the ORF, respectively. A chloramphenicol-resistance determinant integrated into the ORF was mapped by PBS1 transduction, which indicated the gene sequence $d n a E-a r o D-c w l A$.
\end{abstract}

\section{Introduction}

Bacillus subtilis produces cell wall lytic enzymes, some of which are known as autolysins. The major autolysins are the $N$-acetylmuramyl-L-alanine amidase ( $\mathrm{v}$-amidase; Herbold \& Glaser, 1975; Rogers et al., 1984) and the endo- $\beta$ - $N$-acetylglucosaminidase (glucosaminidase; Rogers et al., 1984). These hydrolases affect cell lysis (Fein \& Rogers, 1976; Rogers et al., 1980), cell separation (Fein \& Rogers, 1976), the formation of helices (Mendelson, 1982), flagellation (Fein, 1979) and competence (Ayusawa et al., 1975; Akamatsu \& Sekiguchi, 1987a). During the sporulation stage, two other cell wall hydrolases, s-amidase and $\gamma$-D-glutamyl(L)mesodiaminopimelyl endopeptidase, are formed; they are considered to be associated with the formation of cortex peptidoglycans (Guinand et al., 1976). Some B. subtilis strains (K-77 and YT-25) produce extracellular endo- $\beta$ - $N$-acetylmuramidases (muramidases; Okada \& Kitahara, 1973; Murao \& Takahara, 1974), however, no muramidase activity has been detected in the culture supernatant of $B$. subtilis 168 (Rogers et al., 1980). In

The nucleotide sequence data reported in this paper have been submitted to GenBank and have been assigned the accession number M37710. spite of the extensive biochemical studies, none of the cell wall hydrolase genes of $B$. subtilis have been cloned.

We report here the cloning of a gene, designated $c w l A$, that directs the synthesis of a wall hydrolytic enzyme of $B$. subtilis, together with its complete nucleotide sequence, its mapping and the N-terminal amino acid sequence of the gene product.

\section{Methods}

Bacterial strains, plasmids, phages and media. The strains, plasmids and phages used in this study are listed in Table 1.B. subtilis and E. coli were grown in NB medium ( $10 \mathrm{~g}$ meat extract, $10 \mathrm{~g}$ polypeptone and $3 \mathrm{~g}$ $\mathrm{NaCl}$ per litre, $\mathrm{pH} \mathrm{7.0)}$ and $\mathrm{LB}$ medium $(5 \mathrm{~g}$ yeast extract, $10 \mathrm{~g}$ polypeptone and $10 \mathrm{~g} \mathrm{NaCl}$ per litre, $\mathrm{pH} 7 \cdot 2$ ) at $37^{\circ} \mathrm{C}$, respectively. For determination of auxotrophic requirements, Spizizen minimal medium (Spizizen, 1958) was used. Schaeffer agar medium (Schaeffer et al., 1965) was also used for culturing $B$. subtilis.

Preparation of $B$. subtilis cell wall. Cell walls were prepared essentially as described by Fein \& Rogers (1976). B. subtilis cells harvested from a stationary-phase culture $(15 \mathrm{l})$ were suspended in cold deionized water $(50 \mathrm{ml})$ and disrupted with a bead-beater (Biospec) in a vessel containing glass beads (diam. $0 \cdot 1 \mathrm{~mm}$ ). After low-speed centrifugation $(1400 \mathrm{~g}, 10 \mathrm{~min})$ to remove the glass beads and unbroken cells, the crude cell wall was pelleted at $27000 \mathrm{~g}$ for $5 \mathrm{~min}$ at $4{ }^{\circ} \mathrm{C}$, suspended in $20 \mathrm{ml}$ of a $4 \%(w / v)$ sodium dodecyl sulphate solution and boiled for $10 \mathrm{~min}$. After several washes with a $1 \mathrm{M}-\mathrm{NaCl}$ solution and deionized water, the cell wall was stored at $-80^{\circ} \mathrm{C}$. 
Table 1. Bacterial strains, phages and plasmids

\begin{tabular}{|c|c|c|}
\hline & Genotype & Source or reference* \\
\hline \multicolumn{3}{|c|}{ Bacillus subtilis } \\
\hline $168 \mathrm{~S}$ & $\operatorname{trp} C 2 \operatorname{str} A$ smo-I & Sekiguchi et al. (1988) \\
\hline AC 310 & purB tet-1 smo-1 & Sekiguchi et al. (1988) \\
\hline QB936 & ald-1 aroG932 leuA8 trpC2 & BGSC (kit 7) \\
\hline AC705 & lys dnaE20 aroDI20 asaA4 smo-I & Sekiguchi et al. (1988) \\
\hline $17 \mathrm{cmE}$ & $\operatorname{trpC} 2 \operatorname{str} A$ smo-1 cwlA::cat & This study \\
\hline \multicolumn{3}{|c|}{ Escherichia coli } \\
\hline JM109 & $\begin{array}{l}\text { recAl } \Delta(\text { lac-pro } A B) \text { end } A 1 \text { gyrA96 thi-1 hsdRI7 relAl } \\
\text { supE44 }\left[\mathrm{F}^{\prime}: \text { traD36 proAB lacI }{ }^{\circ} Z \Delta \mathrm{M} 15\right]\end{array}$ & Takara \\
\hline MV1184 & $\begin{array}{c}\text { ara } \Delta(\text { lac-pro }) \text { strA thi }(\phi 80 \text { lac } Z \Delta \mathrm{M} 15) \Delta(\text { srl-rec } A) \\
306:: \operatorname{Tn} 10\left(\text { tet }^{\mathrm{r}}\right)\left[\mathrm{F}^{\prime}: \text { traD36 proAB lac } I^{\natural} Z \Delta \mathrm{M} 15\right]\end{array}$ & Takara \\
\hline \multicolumn{3}{|c|}{ - } \\
\hline PBS1 & & BGSC \\
\hline M13KO7 & & Takara \\
\hline \multicolumn{3}{|l|}{ Plasmid } \\
\hline pUC19 & $\mathrm{Ap}^{\mathrm{r}} \mathrm{Lac}^{+}$ & Yanisch-Perron et al. (1985) \\
\hline pUC118 & $\mathrm{Ap}^{\mathrm{r}} \mathrm{Lac}^{+}$ & Takara \\
\hline pUC119 & $\mathrm{Ap}^{r} \mathrm{Lac}^{+}$ & Takara \\
\hline pUD1 & $\mathrm{Ap}^{r} \mathrm{Cm}^{r}$ & Sekiguchi et al. (1988) \\
\hline
\end{tabular}

* BGSC, Bacillus Genetic Stock Center, The Ohio State University; Takara, Takara Shuzo Co., Kyoto, Japan.

Preparation of plasmids, DNA manipulations and gel electrophoresis. $E$. coli plasmids were prepared by the method of Guerry et al. (1973). Restriction enzymes [Nippon Gene, except for Sau3AI (Takara)], Bal31 (Takara) and E. coli DNA polymerase I (Klenow fragment, Takara) were used according to the manufacturers' recommendations. Agarose (1\%, agarose S; Nippon Gene) gel electrophoresis was performed by the method of Sharp et al. (1973).

Gene library of B. subtilis chromosomal DNA in E. coli. B. subtilis $168 \mathrm{~S}$ chromosomal DNA $(10 \mu \mathrm{g})$, prepared as described by Saito \& Miura (1963) and partially digested with Sau3AI, was subjected to agarose gel electrophoresis. Fragments in the size range $2-10 \mathrm{~kb}$ were recovered from agarose gels using Gene Clean (Biol01). The DNA solution was mixed with pUC19 DNA $(10 \mu \mathrm{g})$, which had been digested with BamHI, followed by dephosphorylation with calf intestine alkaline phosphatase (Boehringer), and ligated with a ligation kit (Takara) for $30 \mathrm{~min}$. The ligated DNA solution was added to competent $E$. coli JM109 cells. The ampicillin-resistant (Apr) colonies were selected on LB agar plates containing $50 \mu \mathrm{g}$ ampicillin $\mathrm{ml}^{-1}$, and used as the gene library.

Selection of E. coli harbouring a B. subtilis cell wall hydrolase gene. The $A p^{r}$ transformants were transferred with toothpicks to LB agar plates containing $B$. subtilis cell wall $\left(0.5 \mathrm{~g} \mathrm{l}^{-1}\right)$ and ampicillin $\left(50 \mu \mathrm{g} \mathrm{ml}^{-1}\right)$, followed by incubation for 1 to $2 \mathrm{~d}$ at $37^{\circ} \mathrm{C}$. Colonies (N6 and N47) exhibiting a zone of lysis (clear zone) were selected. Clones N6 and N47 harboured $6.0 \mathrm{~kb}$ (pBA6) and $9.1 \mathrm{~kb}$ (pBA47) plasmids, respectively.

Construction of pBA47 derivative plasmids. A $2.3 \mathrm{~kb}$ EcoRI fragment of pBA47, which has an overlap with the pBA6 insert, was subcloned into the EcoRI site of pUC118 (Fig. 1). The resulting plasmid (pBA47E) was digested at the Pst I site among the multicloning sites. For construction of $\mathrm{pBA} 47 \mathrm{~B} 1$ and $\mathrm{pBA} 47 \mathrm{~B} 2$, the linearized $\mathrm{pBA} 47 \mathrm{E}$ DNA was digested with Bal 31 and the deleted fragments were made blunt with the Klenow fragment. After digestion with EcoRI, the $E c o$ RI-blunt fragments were recovered by agarose gel electrophoresis, ligated to the EcoRI and SmaI sites of pUC118 DNA, and transformed into $E$. coli MV1184. For construction of pBA47ES, the $1.35 \mathrm{~kb}$ Sau3AI (S1)-EcoRI fragment of pBA47E was cloned into the BamHI and $E c o$ RI sites of pUC118. For pBA47ESR, the $1.35 \mathrm{~kb} X b a \mathrm{I}-E c o \mathrm{RI}$ fragment of pBA47ES was cloned into the $X b a \mathrm{I}$ and $E c o$ RI sites of pUC119. For pBA47EH, a HindIII site among the multicloning sites of pBA47ES was lost by partial digestion with HindIII followed by filling reaction with the Klenow fragment. The resultant plasmid, pBA47ES1, had only one HindIII site. The HindIII-digested pBA47ES1 fragment and a $0.9 \mathrm{~kb}$ EcoRI-HindIII fragment containing the cat gene derived from pUD1 (Sekiguchi et al., 1988) were made blunt with the Klenow fragment and subjected to ligation.

DNA sequencing. Nucleotide sequencing was carried out by the dideoxy-chain termination method (Sanger et al., 1977) with a modified T7 polymerase (Sequenase). Plasmids pUC118 and pUC119 (Takara) were used to generate templates for sequencing, and phage $\mathrm{M} 13 \mathrm{KO} 7$ (Takara) was used as a helper phage. Electrophoresis was performed on $8 \%(\mathrm{w} / \mathrm{v})$ polyacrylamide $/ 8 \mathrm{M}$-urea gels. The sequence of both strands was determined for the $1 \cdot 1 \mathrm{~kb}$ region between sites $\mathrm{S} 1$ and $\mathrm{B} 1$.

Preparation of a cell wall hydrolase. E. coli MV1184 cells harbouring pBA47ES, pBA47ESR or pUC119 were cultured with shaking in LB medium containing ampicillin $\left(50 \mu \mathrm{g} \mathrm{ml}^{-1}\right)$ until early exponential phase was reached. Then isopropyl $\beta$-D-thiogalactoside (IPTG) was added to a portion of cultures at a final concentration of $1 \mathrm{mM}$. After $6 \mathrm{~h}$ incubation at $37^{\circ} \mathrm{C}$, the cell density was measured as $\mathrm{OD}_{540}$, and the $1 \mathrm{ml}$ cultures were exposed to ultrasonication (Tomy BH-200P; pulse time of $30 \mathrm{~s}$, five times, at a power of $180 \mathrm{~W}$ ). More than $90 \%$ of the cells were disrupted by this treatment. After centrifugation, the supernatants were used as enzyme solutions.

Assay of cell wall lytic activity. Lytic activity was measured as described by Ayusawa et al. (1975). The reaction mixture $(5 \mathrm{ml})$ consisted of $B$. subtilis cell wall (to a final $\mathrm{OD}_{540}$ of 0.3 ) in TK buffer $[0 \cdot 1 \mathrm{M}-\mathrm{Tris} / \mathrm{HCl}(\mathrm{pH} 8 \cdot 0), 0 \cdot 1 \mathrm{M}-\mathrm{KCl}]$ and the enzyme extract, and was incubated with slow shaking at $37^{\circ} \mathrm{C}$. Each assay was routinely performed twice. One unit (U) of the enzyme activity was defined as the amount of enzyme necessary to decrease the ${ } D_{540}$ by 0.001 in $1 \mathrm{~min}$.

$\mathrm{N}$-terminal amino acid sequence. The $\mathrm{N}$-terminal amino acid sequence of the cloned enzyme purified from $E$. coli JM109(pBA47) was determined by an automatic peptide sequencer (Applied Biosystems model $470 \mathrm{~A}$ ). 


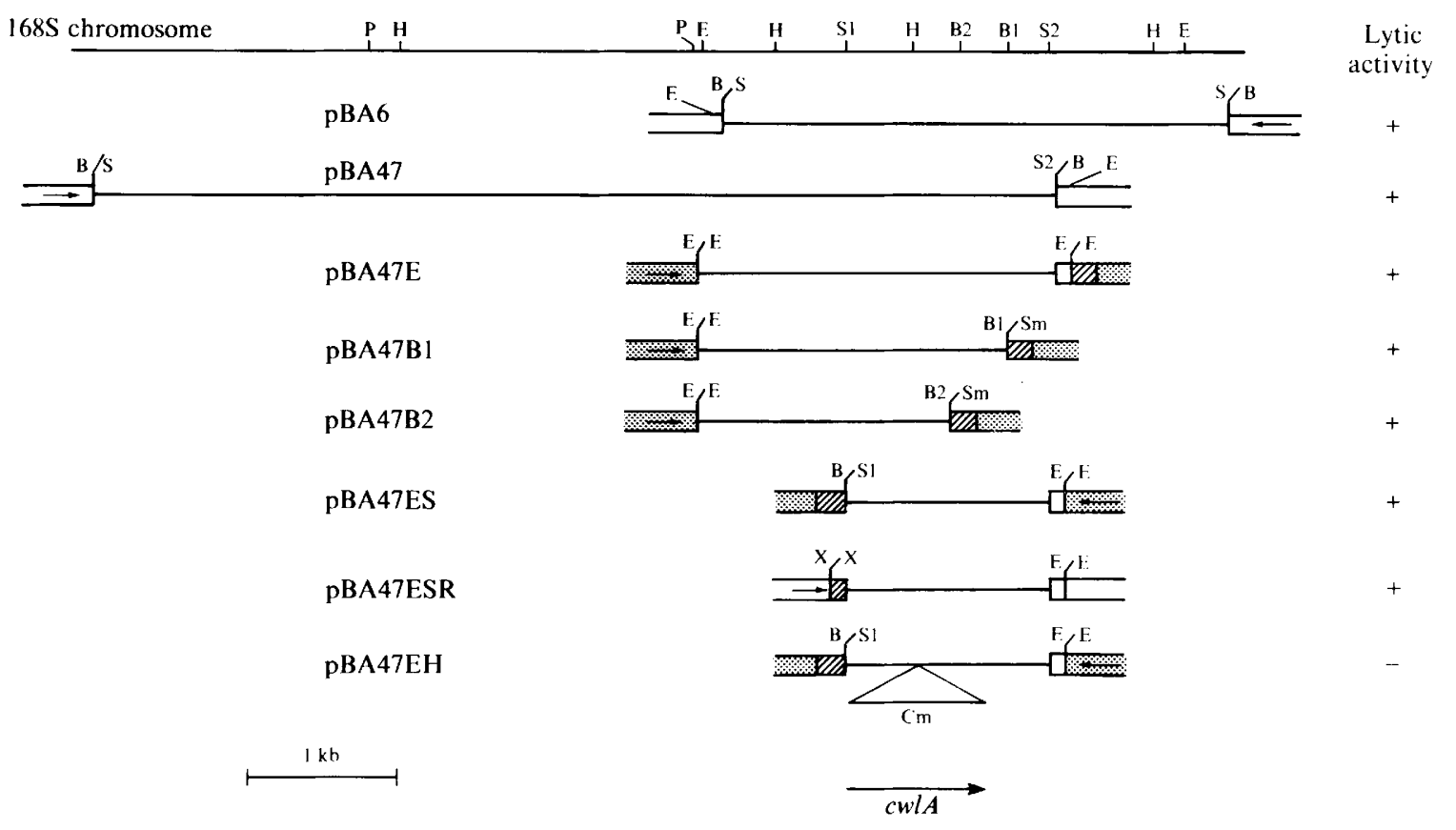

Fig. 1. Restriction map of the inserts of pBA6, pBA47 and its derivatives, and the corresponding region of the B. subtilis chromosome. The cell wall lytic activities of the plasmids in $E$. coli are also given. The construction of derivative plasmids is described in Methods. Lytic activity was identified by the appearance of clear zones around colonies harbouring the plasmids. The open blocks represent pUC19 or pUC119 vector DNAs. Stippled and hatched blocks represent pUC118 and its multiple cloning site regions, respectively. Small arrows indicate the direction of the lac promoter. Relevant Sau3AI sites are indicated. Abbreviations: E, EcoRI sites; H, HindIII; P, PstI; S, S1 and S2, Sau3AI; Sm, SmaI; B, BamHI; B1 and B2, endpoints of deletions generated by Bal31 nuclease; $\mathrm{Cm}$, the $1.0 \mathrm{~kb}$ fragment containing the chloramphenicol acetyltransferase gene (cat) from pUD1 (Sekiguchi et al., 1988). The large arrow represents the coding region of the hydrolase gene and indicates the transcriptional direction.

Transformation and transduction of $B$. subtilis. Transformation of $B$ subtilis was performed according to the procedure of Anagnostopoulos \& Spizizen (1961). Chloramphenicol-resistant $\left(\mathrm{Cm}^{r}\right)$ transformants were selected on NB agar plates containing $5 \mu \mathrm{g}$ chloramphenicol $\mathrm{ml}^{-1}$. PBSI transduction was performed as described by Dubnau et al. (1967). For evaluating the competence of $B$. subtilis $17 \mathrm{cmE}$ and control $168 \mathrm{~S}$, B. subtilis AC310 DNA was used as donor DNA and Trp ${ }^{+}$ transformants were selected.

\section{Results}

Cloning of a B. subtilis cell wall hydrolase gene

Chromosomal DNA of $B$. subtilis 168 S was partially digested with Sau3AI and ligated with BamHI-digested pUC19. E.coli JM109 was transformed with the ligation mixture and plated on LB agar containing ampicillin. After overnight culturing, transformants were picked onto LB agar plates containing $B$. subtilis cell wall $\left(0.5 \mathrm{~g} \mathrm{l}^{-1}\right)$ and ampicillin, and incubated for 1 to $2 \mathrm{~d}$ at $37^{\circ} \mathrm{C}$. Among $5000 \mathrm{Ap}^{\mathrm{r}}$ transformants, two colonies, N6 and $\mathrm{N} 47$, were surrounded by weak clear zones. Clone N47 showed a larger clear zone on an agar plate containing IPTG and the cell wall than did clone N6. Restriction site analysis of plasmids isolated from strains
N6 and N47 indicated the presence of $6.0 \mathrm{~kb}$ (pBA6) and $9.1 \mathrm{~kb}$ (pBA47) plasmids, which contain $3.3 \mathrm{~kb}$ and $6.4 \mathrm{~kb}$ DNA inserts, respectively. The inserts had an overlapping region of $2 \cdot 2 \mathrm{~kb}$.

Derivatives of pBA47 were constructed and the lytic activity of $E$. coli harbouring the plasmids was examined on LB agar plates containing ampicillin and cell wall (Fig. 1). Clear zones were observed for pBA47E, pBA47B1, pBA47B2, pBA47ES and pBA47ESR, but not for pBA47EH, suggesting that the hydrolase gene is located between Sau3AI site S1 and site B2. When E. coli MV1184 harbouring pBA47ES and pBA47ESR were incubated in LB medium containing ampicillin and IPTG ( $1 \mathrm{~mm}$ ), lytic activities were 0.12 and $22.2 \mathrm{U} \mathrm{ml}^{-1}$ per $\mathrm{OD}_{540}$ unit, respectively. Without IPTG they were 0.39 and $1.8 \mathrm{U} \mathrm{ml}^{-1}$ per $\mathrm{OD}_{540}$ unit, respectively. The control, E. coli MV1184(pUC19), with or without IPTG, gave an activity of less than $0.03 \mathrm{U} \mathrm{ml}^{-1}$ per $\mathrm{OD}_{540}$ unit. The DNA fragment inserted in pBA47ES had an orientation opposite to that of the insert in pBA47ESR, downstream from the $l a c$ promoter. There may, therefore, be a weak promoter on the S1 site side in pBA47ES (Fig. 1), the hydrolase gene being transcribed from the $\mathrm{S} 1$ to the $\mathrm{B} 1$ site. 


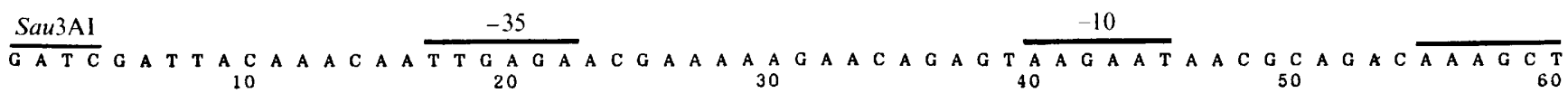

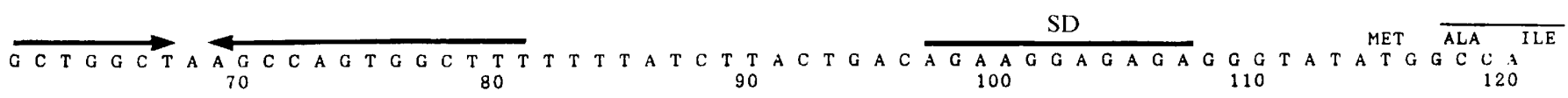

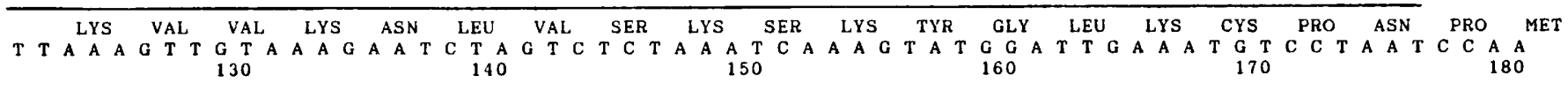

LYS ALA GLU TYR ILE THR ILE HIS ASN THR ALA ASN ASP ALA SER ALA ALA ASN GLU ILE T G A A A G C T G A A T A T A T C A C T A T T CA T A A C A C T G C G A A T GA T G C T T CA G CA G C C A A T G A G A

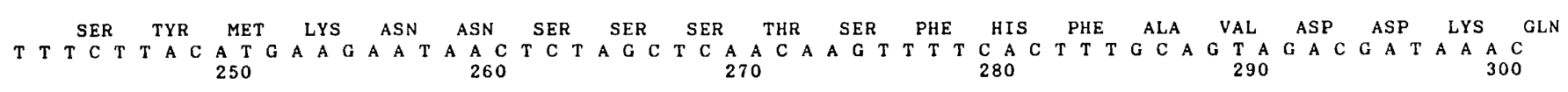

VAL ILE GLN GLY ILE PRO THR ASN ARG ASN ALA TRP HIS THR GLY ASP GLY THR ASN GLY

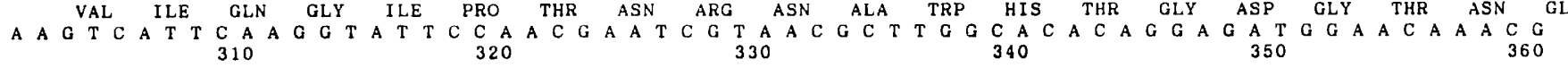

G T THR GLY ASN ARG LYS SER TLE GLY VAL GLU ILE CYS TYR SER LYS SER GLY GLY VAL ARG G T A C A G G G A A T C G C A A G T C C T A T T G G T G T T C G A A A T T T G T T T A T A G C A A G T C A A G G A G G G G T A C HindIII

TYR LYS ALA ALA GLU LYS LEU ALA ILE LYS PHE VAL ALA GLN LEU LEU LYS GLU ARG GLY

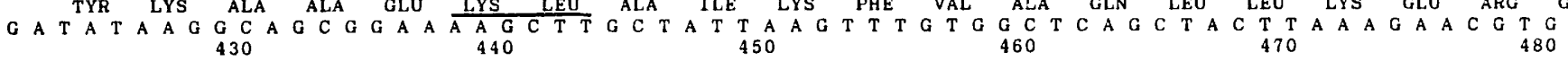

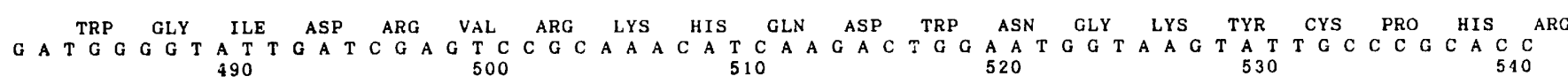

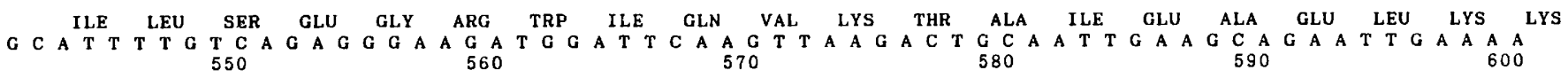

A G TEU GLY GLY LYS THR ASN SER SER LYS ALA SER VAL ALA LYS LYS LYS THR THR ASN THR

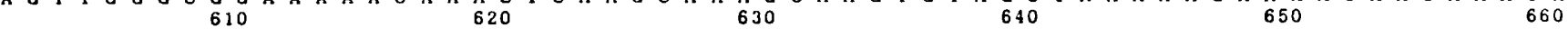

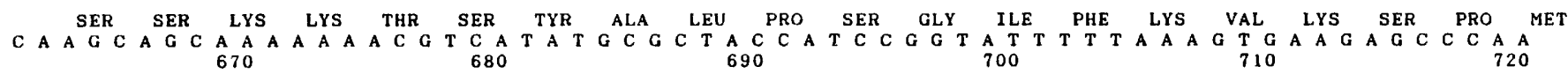
B2

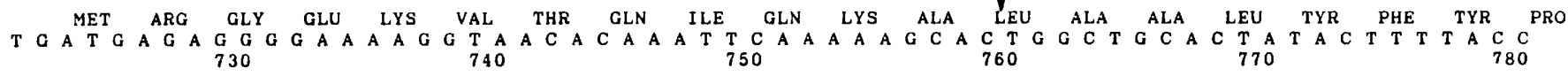

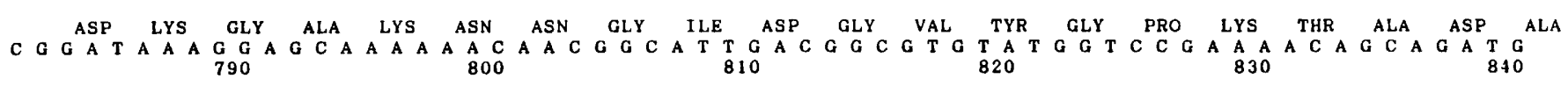

ILE ARG ARG PHE GLN SER MET TYR GLY LEU THR GLN ASP GLY ILE TYR GLY PRO LYS THR

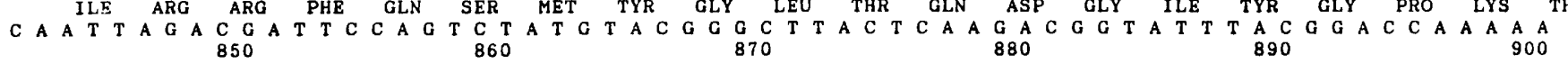

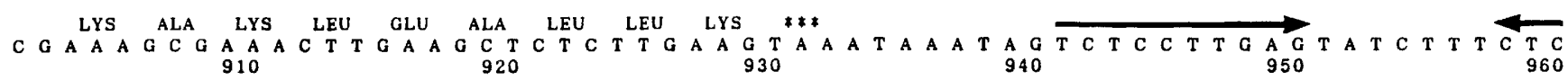

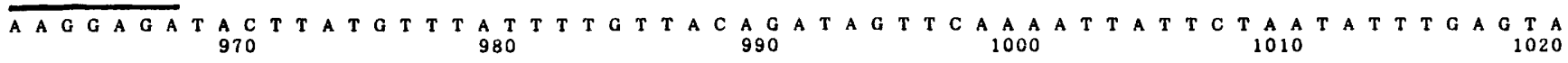

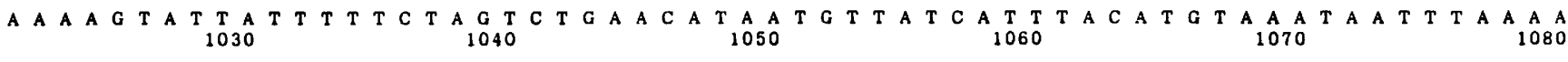

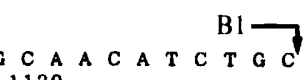
G A A A G G G A T T T
T G T T
A T T

Fig. 2. Nucleotide sequence of the $B$. subtilis $c w l A$ gene. Only the sequence of the nontranscribed DNA strand is shown, from position +1 [Sau3AI (S1) site]. The deduced amino acid sequence is given above the nucleotide sequence. Putative promoter sequences $(-35$ and -10 regions of the vegetative promoter) and terminators (inverted repeat sequences, 55-81 and 941-967), as well as a putative ribosome-binding sequence (SD) (97-107) are indicated. The N-terminal amino acid sequence of the $c w l A$ protein prepared from $E$. coli JM109(pBA47) is overlined. B1 and B2 are the sites shown in Fig. 1. *** indicates a stop codon. 


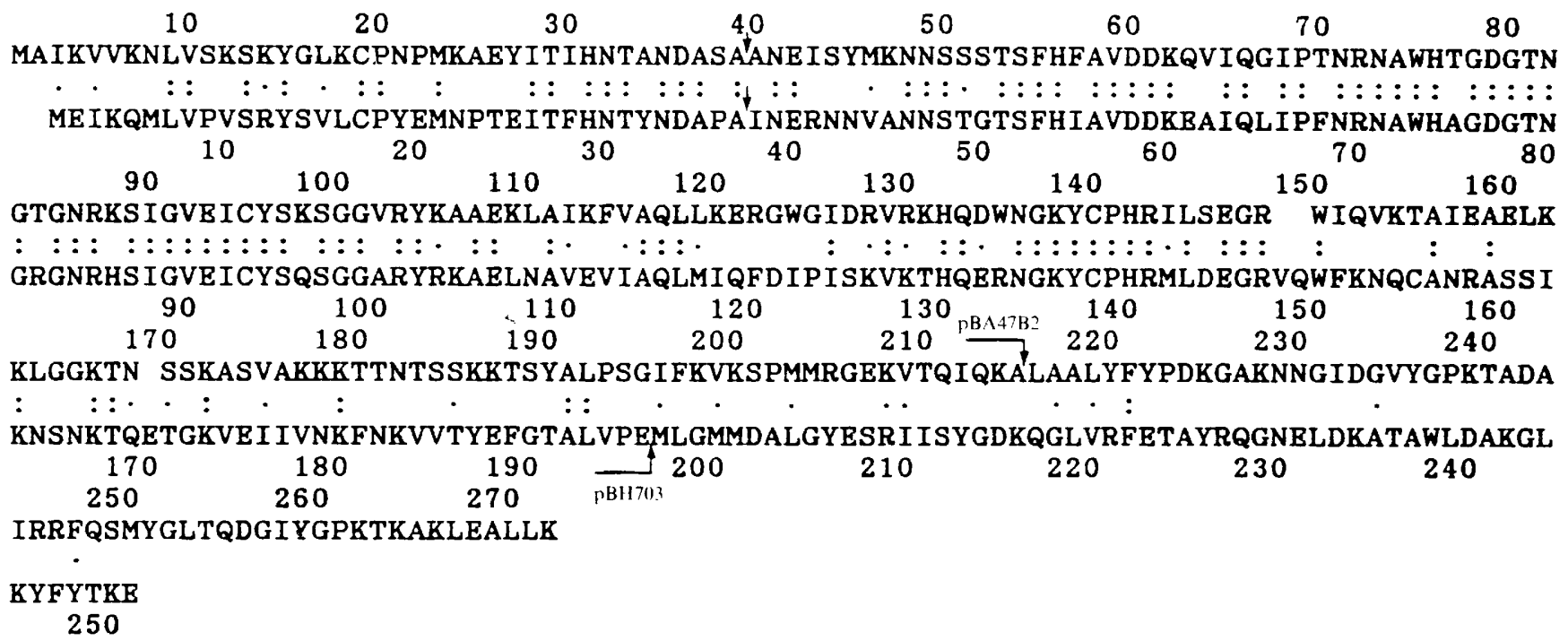

Fig. 3. Comparison of the deduced amino acid sequence of the $c w l A$ gene to that of the Bacillus sp. cell wall hydrolase gene (Potvin $e t$ al., 1988) - upper and lower sequences, respectively. Identical amino acids are indicated by colons. Similar and unrelated amino acids are indicated by dots and blanks, respectively. pBA47B2 and pBH703 (Potvin et al., 1988) are truncated clones whose C-terminals were connected to the 22- and 3-amino acid peptides at the arrow positions, respectively. Downward pointing arrows indicate putative signal sequence cleavage sites (von Heijne, 1986). Conservative substitutions: I, L, V and M; K and R; S and T; D and E; F and Y;N and Q; $\mathrm{G}$ and $\mathrm{A}$.

Southern hybridization of a HindIII and EcoRI double-digested chromosomal DNA from $B$. subtilis with a ${ }^{32}$ P-labelled $2.3 \mathrm{~kb} E c o$ RI fragment of pBA47E showed three hybridized bands $(0.45 \mathrm{~kb}, 0.9 \mathrm{~kb}$ and $1.6 \mathrm{~kb})$, the former two corresponding to the $0.45 \mathrm{~kb}$ EcoRI-HindIII and $0.9 \mathrm{~kb}$ HindIII fragments, respectively, in the insert of pBA47E (data not shown). These data suggest that the cloned DNA was a fragment of the B. subtilis chromosomal DNA and did not have extensive rearrangements.

\section{Nucleotide sequence of the B. subtilis cell wall hydrolase} gene

The S1-B1 fragment, of approximately $1.1 \mathrm{~kb}$, was sequenced (Fig. 2). The sequence showed one long ORF, starting at nucleotide 114 and ending at nucleotide 929 , which encodes a polypeptide of 272 amino acid residues with a molecular mass of $29919 \mathrm{Da}$. A putative signal sequence cleavage site was found after $\mathrm{Ala}_{39}$ in the sequence $\mathrm{Ala}_{37}-\mathrm{Ser}_{38}-\mathrm{Ala}_{39}-\mathrm{Ala}_{40}$ (Fig. 3). The first ATG was preceded by a possible ribosome-binding site, AGAAGGAGAGA ( $\Delta \mathrm{G}=-14.9 \mathrm{kcal} \mathrm{mol}^{-1}$; the consensus sequence is underlined) and a potential rhoindependent terminator followed the ORF. Interestingly, another potential rho-independent terminator was found upstream of the ORF. The sequences at nucleotide 17 (TTGAGA, putative -35 sequence) and nucleotide 40 (AAGAAT, putative Pribnow box), and the $17 \mathrm{bp}$ space between the two suggested the existence of a $\sigma^{\mathrm{A}}$ promoter, which is recognized by the major $E$. coli RNA polymerase (Hawley \& McClure, 1983).

The cell wall hydrolase was extracted from $E$. coli JM109(pBA47) cells and purified using hydroxyapatite column chromatography and HPLC (TSK-gel $\mathrm{G} 3000 \mathrm{SW} \mathrm{XL}_{\mathrm{XL}}$; results not shown). The $\mathrm{N}$-terminal amino acid sequence was AIKVVKNLVSKSKYGLKCPN, which is consistent with that of the deduced sequence starting from Ala at nucleotide 117 in Fig. 2.

Comparison of the deduced amino acid sequence of the ORF with other protein sequences revealed an overall identity of $35 \%$ (on pairwise comparison) with the Bacillus sp. cell wall hydrolase gene, reported to be a major autolysin (Fig. 3; Potvin et al., 1988). The homologous sites were located in the $\mathrm{N}$-terminal and central regions of the protein. Therefore the ORF was tentatively designated $c w l A$ (cell wall lysis). Plasmid pBA47B2, a truncated clone of the cwlA gene (57 deduced amino acid residues from the $\mathrm{C}$-terminus were replaced by 22 deduced amino acid residues from pUC118) retained lytic activity (Figs 1 and 3). Therefore, it would appear that the essential site(s) for the enzyme activity is in the $\mathrm{N}$-terminal to central region of the protein. Computer analysis (IDEAS sequence analysis system on the NBRF protein database, Release 16.0, Kyushu University) revealed a striking similarity between the $\mathrm{C}$-terminal sequence of the $c w l A$ gene product and the $\mathrm{N}$-terminal sequence of muramoylpentapeptide carboxypeptidase of Streptomyces albus G 


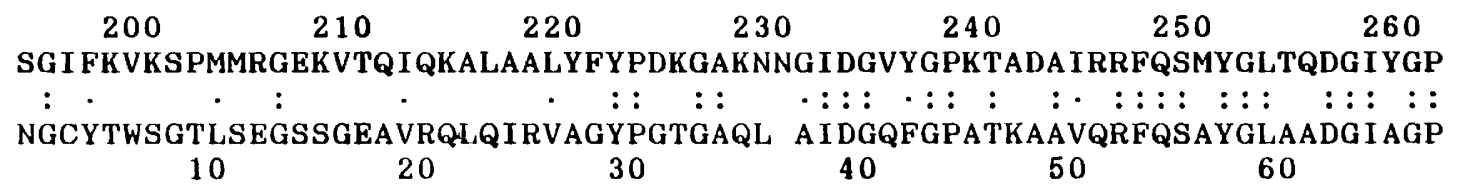

Fig. 4. Comparison of the deduced amino acid sequence of the $c w l A$ gene with that of the muramoyl-pentapeptide carboxypeptidase (Dideberg et al., 1982; Joris et al., 1983) - upper and lower sequences, respectively. The numbers above the $c w l A$ sequence and below the carboxypeptidase sequence are the positions with respect to the $\mathrm{N}$-terminal amino acids. Dots, blanks and conservative substitutions are as for Fig. 3.

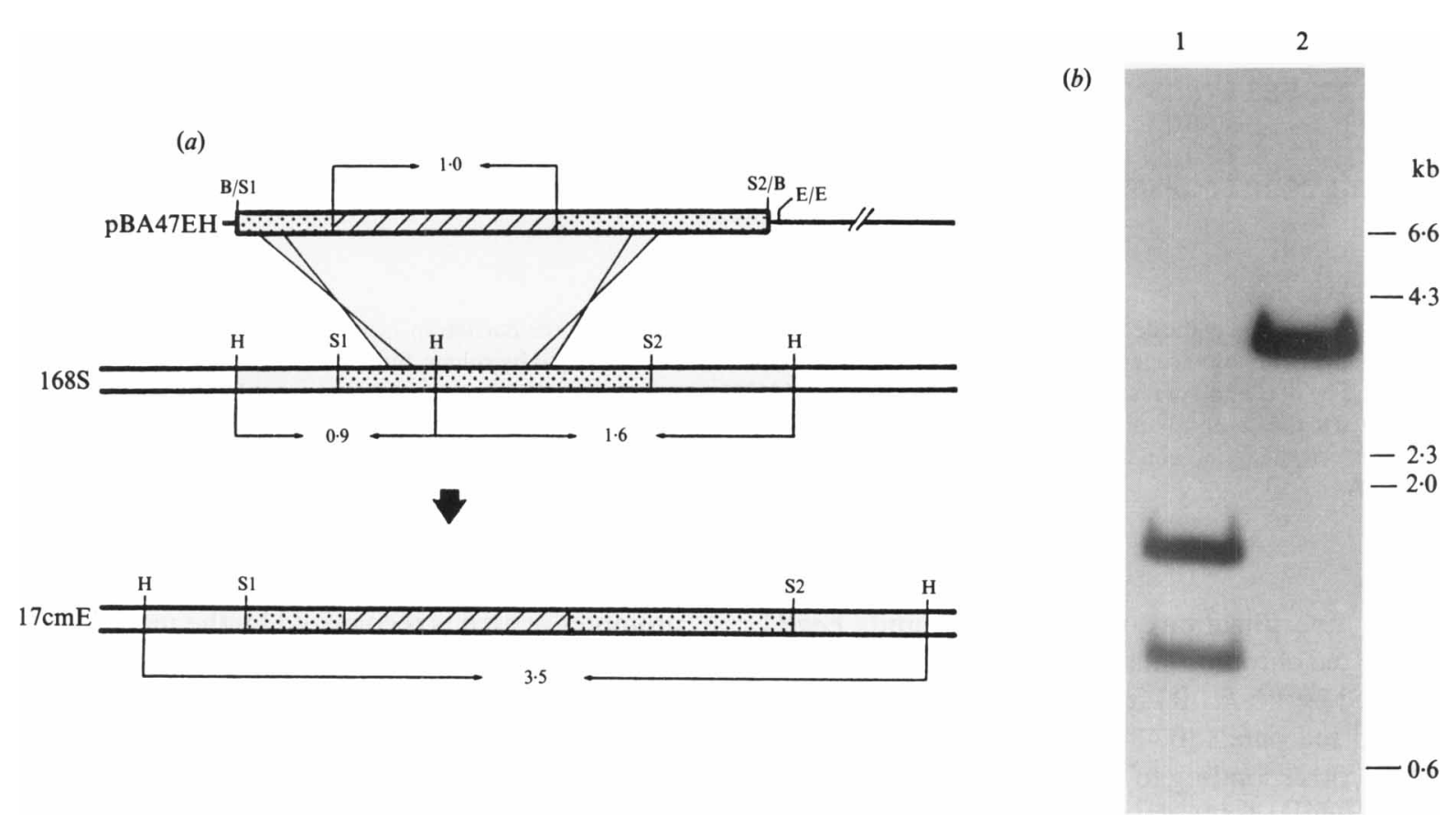

Fig. 5. (a) Insertional mutation of the chromosomal $c w l A$ gene by transformation with linearized pBA47EH. The hatched, stippled and open blocks, and the line represent the fragments containing the $c a t$ and $c w l A$ genes, $B$. subtilis DNA (except $c w l A$ ) and pUC118 DNA, respectively. The distances are shown in $\mathrm{kb}$. Abbreviations as in Fig. 1. (b) Southern transfer and hybridization of restriction-enzymedigested DNAs from $B$. subtilis $168 \mathrm{~S}$ and $17 \mathrm{cmE}$ with the $X b a \mathrm{I}-E c o$ RI fragment of pBA47ES as a probe. The $1.3 \mathrm{~kb} X b a \mathrm{I}-E c o \mathrm{RI}$ fragment of pBA47ES containing the $c w l A$ gene was separated by gel electrophoresis and labelled with a nick-translation kit (Takara) containing $\left[\alpha^{-32} \mathrm{P}\right] \mathrm{dATP}$ (Institute of Isotopes of the Hungarian Academy of Sciences). Southern transfer and hybridization were carried out as described previously (Sekiguchi et al., 1988). Lanes 1 and 2,168S and 17cmE chromosomal DNAs, respectively, digested with HindIII. The sizes of the $\lambda$ HindIII fragments are shown on the right.

(EC 3.4.17.8; Dideberg et al., 1982; Joris et al., 1983) (Fig. 4).

\section{Disruption of the cwlA gene by means of insertional inactivation}

To examine the physiological role of the $c w l A$ gene, B. subtilis cwlA : : cat was constructed. A hybrid plasmid, pBA47EH, was obtained by insertion of the cat gene at the HindIII site of the $c w l A$ gene. Competent $B$. subtilis $168 \mathrm{~S}$ cells were transformed with the EcoRI-digested linearized pBA47EH, and $\mathrm{Cm}^{\mathrm{r}}$ transformants were selected (Fig. 5a). To examine the resulting insertionally inactivated mutants, chromosomal DNA was extracted from the transformants, digested with HindIII and subjected to agarose gel electrophoresis, followed by Southern blot hybridization analysis (Fig. 5b). The $X b a I-E c o$ RI fragment from pBA47ES containing the $c w l A$ gene as a probe hybridized to one band at $3.5 \mathrm{~kb}$, whereas it hybridized to HindIII-digested B. subtilis $168 \mathrm{~S}$ chromosomal DNA fragments at $0.9 \mathrm{~kb}$ and $1.6 \mathrm{~kb}$. Since pBA47EH contained a $1.0 \mathrm{~kb}$ cat insert, double cross-over integration, leading to inactivation of the $c w l A$ gene (Fig. $5 a$ ), is indicated. The constructed B. subtilis $17 \mathrm{cmE}$ and two similar $\mathrm{Cm}^{\mathrm{r}}$ transformants showed normal cell morphology. Competence was retained at normal levels $\left(1.2 \times 10^{4}\right.$ and $0.82 \times 10^{4}$ transformants per $\mu \mathrm{g}$ DNA for $17 \mathrm{cmE}$ and $168 \mathrm{~S}$, 
Table 2. Linkage relationships of an integrated antibiotic marker with standard markers, determined with PBS1

\begin{tabular}{|c|c|c|c|c|}
\hline $\begin{array}{c}\text { Donor } \\
\text { (genotype) }\end{array}$ & $\begin{array}{l}\text { Recipient } \\
\text { (genotype) }\end{array}$ & $\begin{array}{l}\text { Selected } \\
\text { marker }\end{array}$ & Phenotype & Number \\
\hline $\begin{array}{l}\text { B. subtilis } 17 \mathrm{cmE} \text { (trpC2 } \\
\text { strA smo-1 cwlA::cat) }\end{array}$ & $\begin{array}{l}\text { B. subtilis AC705 (lys dnaE20 } \\
\text { aroD120 asaA4 smo-1) }\end{array}$ & $\mathrm{Cm}^{\mathrm{r}}$ & $\begin{array}{l}\mathrm{Ts}^{-*} \mathrm{Aro}^{-} \\
\mathrm{Ts}^{+} \mathrm{Aro}^{-} \\
\mathrm{Ts}^{-} \mathrm{Aro}^{+} \\
\mathrm{Ts}^{+} \mathrm{Aro}^{+}\end{array}$ & $\begin{array}{r}7 \\
0 \\
32 \\
61\end{array}$ \\
\hline & $\begin{array}{l}\text { B. subtilis QB936 (ald-1 } \\
\text { aroG932 leuA8 trpC2) }\end{array}$ & $\mathrm{Cm}^{\mathrm{r}}$ & $\begin{array}{l}\mathrm{Aro}^{-} \mathrm{Leu}^{-} \\
\mathrm{Aro}^{+} \mathrm{Leu}^{-} \\
\mathrm{Aro}^{-} \mathrm{Leu}^{+} \\
\mathrm{Aro}^{+} \mathrm{Leu}^{+}\end{array}$ & $\begin{array}{r}97 \\
0 \\
3 \\
0\end{array}$ \\
\hline
\end{tabular}

* The dnaE mutant is temperature-sensitive. Temperature sensitivity was examined at $48{ }^{\circ} \mathrm{C}$ (nonpermissive) and $30^{\circ} \mathrm{C}$ (permissive): + , wild-type; -, temperature sensitive.

respectively). After $3 \mathrm{~d}$ incubation on Schaeffer agar medium containing $B$. subtilis cell walls, strains $17 \mathrm{cmE}$ and $168 \mathrm{~S}$ showed clear zones of identical size.

\section{Mapping of the cwlA gene}

The $c w l A$ gene was mapped by transduction of $B$. subtilis strains AC705 and QB936, transduced with a PBS1 lysate obtained on $B$. subtilis $17 \mathrm{cmE}$. $\mathrm{Cm}^{\mathrm{r}}$ was closely linked to $\operatorname{aroD}\left(227^{\circ} ; 93 \%\right.$ linkage $)$ and $d n a E\left(223^{\circ} ; 61 \%\right)$ (Zeigler \& Dean, 1989; Table 2), and the gene order was dnaE-aroD-Cm $(c w l A)$. Weak linkage to leu $A\left(250^{\circ} ; 3 \%\right)$ was also observed (Table 2).

\section{Discussion}

The deduced amino acid sequence of the $B$. subtilis $\mathrm{cwlA}$ gene showed distinct homology with that of the Bacillus sp. cell wall hydrolase gene. The homology was highest for the 180 amino acids starting from the $\mathrm{N}$-terminus, 93 of which were identical. Inactivation of the $c w l A$ gene, by insertion of cat after $\operatorname{Lys}_{109}$, was accompanied by loss of lytic activity. However, the product of pBA47B2, whose $57 \mathrm{C}$-terminal amino acid residues were replaced by another peptide ( 22 amino acids) (Fig. 3), and the truncated Bacillus sp. hydrolase, whose $55 \mathrm{C}$-terminal amino acids were replaced by three amino acids, both retained their lytic activity (Potvin et al., 1988). Therefore, for both enzymes, the homologous $\mathrm{N}$-terminal to central region seems to be functionally important. In spite of poor homology at the C-terminal, the average hydrophilicity profile (running average: 5 amino acids) of the $c w l A$ protein was similar to that of the Bacillus sp. hydrolase (229-262 amino acid sequence of cwlA vs 216-249 of Bacillus sp.) (data not shown).

The carboxypeptidase of $S$. albus $\mathrm{G}$, whose N-terminal amino acid sequence was homologous to the C-terminal region of the deduced amino acid sequence of $c w l A$ gene (Fig. 4), hydrolyses D-alanyl-D-alanine-terminated peptidoglycan precursors. It also effectively hydrolyses a variety of C-terminal $N^{\alpha}$-(D-alanyl)-D- linkages that cross-link the peptidoglycan unit in certain cell walls and, consequently, causes cell wall lysis (Ghuysen $e t$ al., 1970). It consists of two globular domains (Dideberg et al., 1982; Joris et al., 1983); the small N-terminal domain (76 residues) which contains three $\alpha$-helices, and a large C-terminal domain (136 residues) which contains three histidine residues (ligands of a catalytic zinc atom) and an arginine, probably involved in substrate binding (Dideberg et al., 1982; Joris et al., 1983). Therefore, it is interesting to know the role of the C-terminal region of the $c w l A$ product and the $\mathrm{N}$-terminal domain of the $S$. albus $\mathrm{G}$ enzyme. The deduced molecular mass of the $c w l A$ gene product is $29.9 \mathrm{kDa}$, and is likely to be smaller upon processing between the $\mathrm{Ala}_{39}-\mathrm{Ala}_{40}$ residues (Fig. 3 ). This hydrolase is therefore clearly distinct from the two major $B$. subtilis autolysins, the v-amidase and the glucosaminidase, which have molecular weights of $50 \mathrm{kDa}$ (Herbold \& Glaser, 1975), and $90 \mathrm{kDa}$ (Rogers et al., 1984), respectively. In addition, insertional inactivation of the $c w l A$ gene (strain $17 \mathrm{cmE}$ ) did not lead to a decrease of total cell wall lytic activity at $\mathrm{pH} 8.0$, the optimal $\mathrm{pH}$ for the $B$. subtilis v-amidase. We have recently purified the $c w l A$ protein, from $E$. coli (pBA47), and shown it to have a molecular mass of $22.5 \mathrm{kDa}$ (unpublished). Since the ORF of $c w l A$ encodes a polypeptide with a molecular mass of $29.9 \mathrm{kDa}$, and the deduced $\mathrm{N}$-terminal amino acid, methionine, has been processed to form the mature protein, processing in the $\mathrm{C}$-terminal region is also suggested. The cell wall lytic activity was uninhibited by a high concentration of ampicillin (100 mM), showed an optimal $\mathrm{pH}$ of 8.0 , and did not cause an increase in reducing sugars after cell wall digestion (data not shown). Therefore, the cloned enzyme was neither a known v-amidase nor the glucosaminidase. 
A homologous sequence followed by an inverted repeat region and a $T$-rich region were found in the upstream regions of the $c w l A$ and $s a c B$ genes (Aymerich et al., 1986), but not in that of the Bacillus sp. hydrolase gene (Potvin et al., 1988). This may be the cause of the low expression of the $B$. subtilis $\mathrm{cwl} A$ gene relative to that of the Bacillus sp. hydrolase gene (Potvin et al., 1988; unpublished result). The upstream region of $c w l A$ has another curious sequence which is homologous to the upstream regions of $a p r E$ and $s a c B$ genes, which contain the targets for $s a c U^{\mathrm{h}}$ and $s a c Q^{\mathrm{h}}$ products (Henner et al., 1988). In particular, higher homology was found between $c w l A$ and $s a c B$ in the target sequences (18 of 22 bases homologous) as well as in the adjacent regions (9 to 13).

The $c w l A$ gene does not correspond to the faD gene, mutations in which cause a decrease in lytic activity, because the loci were different $\left(\operatorname{flaD}\left(218^{\circ}\right)-d n a E\right.$-aroDcwlA (Akamatsu \& Sekiguchi, 1987a, b; Table 2). Moreover, there was no significant homology between the $c w l A$ gene and the Streptococcus pneumoniae amidase gene (autolysin gene) cloned by López and his colleagues (García et al., 1985, 1986).

Since the physiological role of the $c w l A$ protein in $B$. subtilis is obscure, we are now researching the expression and regulation of the $c w l A$ gene in $B$. subtilis.

We would like to thank Professor A. Amemura, Fukuyama University, for determining the $\mathrm{N}$-terminal amino acid sequence.

\section{References}

Akamatsu, T. \& Sekiguchi, J. (1987a). Genetic mapping and properties of filamentous mutations in Bacillus subtilis. Agricultural and Biological Chemistry 51, 2901-2909.

Akamatsu, T. \& Sekiguchi, J. (1987b). Genetic mapping by means of protoplast fusion in Bacillus subtilis. Molecular and General Genetics 208, 254-262.

Anagnostopoulos, C. \& Spizizen, J. (1961). Requirements for transformation in Bacillus subtilis. Journal of Bacteriology 81, 741-746.

Aymerich, S., Gonzy-Tréboul, G. \& Steinmetz, M. (1986). $5^{\prime}$-Noncoding region $s a c R$ is the target of all identified regulation affecting the levansucrase gene in Bacillus subtilis. Journal of Bacteriology 166, 993-998.

Ayusawa, D., Yoneda, Y., Yamane, K. \& Maruo, B. (1975). Pleiotropic phenomena in autolytic enzyme(s) content, flagellation, and simultaneous hyperproduction of extracellular $\alpha$-amylase and protease in a Bacillus subtilis mutant. Journal of Bacteriology 124, $459-469$

Dideberg, O., Charlier, P., Dive, G., Joris, B., Frére, J. M. \& GHuYsen, J. M. (1982). Structure of a $\mathrm{Zn}^{2+}$-containing D-alanylD-alanine-cleaving carboxypeptidase at $2.5 \AA$ resolution. Nature, London 299, 469-470.

Dubnau, D., Goldthwaite, C., Smith, I. \& Marmur, J. (1967). Genetic mapping in Bacillus subtilis. Journal of Molecular Biology 27, 163-185.

Fein, J. E. (1979). Possible involvement of bacterial autolytic enzymes in flagellar morphogenesis. Journal of Bacteriology 137, 933-946.

FEIN, J. E. \& Rogers, H. J. (1976). Autolytic enzyme deficient mutants of Bacillus subtilis 168. Journal of Bacteriology 127, 1427-1442.

García, E., García, J.-L., Ronda, C., García, P. \& LóPez, R. (1985). Cloning and expression of the pneumococcal autolysin gene in Escherichia coli. Molecular and General Genetics 201, 225-230.
García, P., García, J. L., García, E. \& López, R. (1986). Nucleotide sequence and expression of the pneumococcal autolysin gene from its own promoter in Escherichia coli. Gene 43, 265-272.

Ghuysen, J.-M., Leyh-Bouille, M., Bonaly, R., Nieto, M., Perkins, H. R., SCHLEIFER, K. H. \& KANDLER, O. (1970). Isolation of DD carboxypeptidase from Streptomyces albus G culture filtrates. Biochemistry 9, 2955-2961.

GuerRY, P., LeBlanc, D. J. \& Falkow, S. (1973). General method for the isolation of plasmid deoxyribonucleic acid. Journal of Bacteriology 116, 1064-1066.

Guinand, M., Michel, G. \& Balassa, G. (1976). Lytic enzymes in sporulating Bacillus subtilis. Biochemical and Biophysical Research Communications 68, 1287-1293.

HAWley, D. K. \& McCluRE, W. R. (1983). Compilation and analysis of Escherichia coli promoter DNA sequences. Nucleic Acids Research 11, 2237-2255.

voN HeIJNE, G. (1986). A new method for predicting signal sequence cleavage sites. Nucleic Acids Research 14, 4683-4690.

HenNer, D. J., YaNG, M. \& Ferrari, E. (1988). Localization of Bacillus subtilis $\operatorname{sac} U(\mathrm{Hy})$ mutations to two linked genes with similarities to the conserved procaryotic family of two-component signalling systems. Journal of Bacteriology 170, 5102-5109.

HeRBOLD, D. R. \& GLASER, L. (1975). Bacillus subtilis $N$-acetylmuramic acid L-alanine amidase. Journal of Biological Chemistry 250, 1676-1682.

Joris, B., Beeumen, J. V., Casagrande, F., Gerday, C., Frére, J.-M. \& GHUYSEN, J.-M. (1983). The complete amino acid sequence of the $\mathrm{Zn}^{2+}$-containing $\mathrm{D}$-alanyl-D-alanine-cleaving carboxypeptidase of Streptomyces albus G. European Journal of Biochemistry 130, 53-69.

MENDELSON, N. H. (1982). Bacterial growth and division: genes, structures, forces, and clocks. Microbiological Reviews 46, 341-375.

Murao, S. \& TaKaHara, Y. (1974). Enzymes lytic against Pseudomonas aeruginosa produced by Bacillus subtilis YT-25. Agricultural and Biological Chemistry 38, 2305-2316.

Okada, S. \& Kitahata, S. (1973). Purification and some properties of bacterial lysozyme. Journal of Fermentation Technology 51, 705-712.

Potvin, C., Leclerc, D., Tremblay, G., Asselin, A. \& Bellemare, G. (1988). Cloning, sequencing and expression of a Bacillus bacteriolytic enzyme in Escherichia coli. Molecular and General Genetics 214, 241-248.

Rogers, H. J., Perkins, H. R. \& Ward, J. B. (1980). Microbial Cell Walls and Membranes. London: Chapman and Hall.

Rogers, H. J., TAYlor, C., RAYTer, S. \& WARD, J. B. (1984). Purification and properties of autolytic endo- $\beta$ - $N$-acetylglucosaminidase and the $N$-acetylmuramyl-L-alanine amidase from Bacillus subtilis strain 168. Journal of General Microbiology 130, 2395-2402.

SaIto, H. \& MiURA, K. (1963). Preparation of transforming deoxyribonucleic acid by phenol treatment. Biochimica et Biophysica Acta 72, 619-629.

Sanger, F., Nicklen, S. \& Coulson, A. R. (1977). DNA sequencing with chain-terminating inhibitors. Proceedings of the National Academy of Sciences of the United States of America 74, 5463-5467.

Schaeffer, P., Millet, J. \& Aubert, J. P. (1965). Catabolite repression of bacterial sporulation. Proceedings of the National Academy of Sciences of the United States of America 54, 704-711.

Sekiguchi, J., Ezaki, B., Kodama, K. \& Akamatsu, T. (1988). Molecular cloning of a gene affecting the autolysin level and flagellation in Bacillus subtilis. Journal of General Microbiology 134 1611-1621

Sharp, P. A., Sugden, B. \& Sambrook, J. (1973). Detection of two restriction endonuclease activities in Haemophilus parainfluenzae using analytical agarose-ethidium bromide electrophoresis. Biochemistry 12, 3055-3063.

SPIZIZEN, J. (1958). Transformation of biochemically deficient strains of Bacillus subtilis by deoxyribonucleate. Proceedings of the National Academy of Sciences of the United States of America 44, 1072-1078.

Yanisch-Perron, C., Vieira, J. \& Messing, J. (1985). Improved M13 phage cloning vectors and host strains: nucleotide sequences of the M13 mpl8 and pUC19 vectors. Gene 33, 103-119.

Zeigler, D. R. \& Dean, D. H. (1989). Bacillus Genetic Stock Center Strains \& Data, 4th edn. Columbus: The Ohio State University. 